\title{
THE VERTICAL DISPERSION OF ANOPHELES (KERTESZIA) CRUZI IN A FOREST IN SOUTHERN BRAZIL SUGGESTS THAT HUMAN CASES OF MALARIA OF SIMIAN ORIGIN MIGHT BE EXPECTED
}

\author{
LEONIDAS M. DEANE, ${ }^{*}$ JOAQUIM A. FERREIRA NETO** \& MILTON MOURA LIMA***
}

\begin{abstract}
By staining females of Anopheles cruzi with fluorescent coloured powders in a forest in the State of Santa Catarina, we showed that they move from canopy to ground and vice-versa to feed. This suggests that in areas where this mosquito is a vector of human and simian malarias sporadic infections of man with monkey plasmodia might be expected.
\end{abstract}

In Brazil, a large proportion of monkeys of various species, spread over many forested areas are parasitized with plasmodia, Plasmodium brasilianum and/or Plasmodium simium, which are infective for humans through mosquito bite (Contacos et al., 1966; Deane, Deane \& Ferreira Neto, 1966). Although in some such areas man and monkeys live in close proximity, the transmission cycles of human and simian malarias are usually independent, being achieved by different species of anophelines that either feed near the ground or prefer to bite at the canopy.

However, in a highly enzootic area of simian malaria in the State of São Paulo, the Horto Florestal da Cantareira, a forest reserve in the outskirts of the State capital, it has been discovered (Deane et al., 1970) that the infection among the monkeys is transmitted by Anopheles (Kerteszia) cruzi, the same species which, since the early $1940 \mathrm{~s}$ is known to be an important vector of human malaria in Southern Brazil. It has also been verified that the vertical distribution of $A$. cruzi varies in different areas. In some of these areas comparative captures were made on baits placed at the canopy and on the ground: in Santa Leopoldina (State of Espírito Santo) and Horto Florestal da Cantareira (State of São Paulo), $99.5 \%$ and $99.3 \%$ of the total numbers of $A$. cruz $i$ caught came from the canopy, while in forested rural areas of the municipality of Joinville (State of Santa Catarina), the yields were $58 \%$ and $42 \%$ from the canopy and from the ground level, respectively; simian plasmodia were present in all three areas (in $31 \%, 62 \%$ and $46 \%$ of the monkeys examined, respectively), but human malaria was non-existant in the first two and endemic in the third (Deane et al., 1971).

Due to the afore mentioned differences it seemed important to investigate if the mosquito being diagnosed as $A$. cruz $i$ is one single species with distinct habits in different areas due to environmental conditions, or a complex of two cryptic species, one biting at the canopy and transmitting simian malaria and the other at ground level, conveying the human parasites. No differences were detected in a detailed morphological study of all stages obtained from females caught at the two levels ${ }^{\circ}$ and the field experiments described below demonstrated that $A$. cruz $i$ can easily move from canopy to ground and vice-versa, at least in some forests.

\section{MATERIAL AND METHODS}

Study area. A forest in Tapera, a hamlet about three kilometers from the village of São Francisco do Sul (26014'37' S and 48038'22" W) in the Northern coast of the State of Santa Catarina was selected because it was one of the few places in Brazil, outside the Amazon Region, where human malaria transmission persisted and where $A$. cruzi was known to be very abundant and practically the only anopheline of the subgenus Kerteszia.

Methodology. This consisted simply in: 1) capturing the kerteszias (easily recognized with the naked eye) alighting on human baits placed either at the canopy or on the ground;2) painting the mosquitoes with a coloured fluorescent powder and releasing them again at the place where they had been captured; 3) making successive captures thereafter, on human baits placed at the opposite level, and 4) identifying painted specimens among the mosquitoes collected in these follow-up captures.

This work was partially supported by Conselho Nacional de Desenvolvimento Cientítıco e Tecnológico (CNPq), grant no. 2222.8.099/80 and Superintendência das Campanhas do Ministério da Saúde (SUCAM), Brazil.

*Instituto Oswaldo Cruz, Departamento de Entomologia, Caixa Postal 926, 20000 Rio de Janeiro, RJ, Brazil.

* SliCAM, District of Santa Catarina, Brazil.

**Formerly at SLCAM and Panamerican Health Organization.

Reccived for publication March 1st and accepted March 26th, 1984

${ }^{\circ}$ To be published by L.M. Deane, J. Ferreira Neto, M.E. Arruda, A.B. Galvão, N. Guitton \& W. de Souza. 
For the canopy captures two men stayed on the branches of a tree, twelve meters above the ground and reached with the help of a rope ladder; the ground captures were made on two people standing close to the trunk of the same tree. These people were well trained field assistants, volunteering to act both as human baits and mosquito collectors. The kerteszias were captured with a Castro collecting tube and transferred to cardboard cups covered with nylon net, 25 to each cup; in a plastic box the cups were transported to a hut about two kilometers distant, where the mosquitoes were painted. This was done by introducing through the nylon cover of each cup the fine tip of a Pasteur pipette containing yellow fluorescent powder, which was blown over the mosquitoes by gently pressing a rubber nipple adapted to the other end of the pipette. The cups were then transported back to the tree canopy and the mosquitoes released.

In the ground captures, transportation, painting and release of the kerteszias were as above, except that the fluorescent powder was red.

In the collections following the release of the painted specimens all mosquitoes were captured and kept individually in $6 \mathrm{~cm} \times 2.5 \mathrm{~cm}$ tubes to prevent contamination with the coloured powder carried on the kerteszias that had been stained. The tubes were then transported to the laboratory of the Anti-Malaria Campaign in São Francisco do Sul where, in a darkened room and with the help of an ultra-violet lamp (Black Ray Long Wave UVL 56, 115 volts, 60HZ, 118 amperes, Ultra-violet Products Inc., San Gabriel, California, USA) the painted specimens were spotted. Stained and unstained specimens were kept in different boxes, counted and examined microscopically for confirmation of species diagnosis.

\section{RESULTS}

The experiments were carried out from 3 to 6 March, 1983. In two the displacement from canopy to ground was observed; in one, from ground to canopy.

More captures had been programmed than was possible to perform, because of the heavy rains downpouring on the area at the time. Even so, results were quite clear, as shown in Table I, in which data are presented on the initial captures performed either at the canopy or at ground level when the mosquitoes were collected, stained and released, and the subsequent follow-up captures, when the stained specimens were searched for at the opposite level. All mosquitoes from the follow-up captures were identified as $A$. cruzi.

\section{TABLE I}

Experiments on the vertical dispersion of Anopheles cruzi in a forest, Tapera, municipality of São Francisco do Sul, State of Santa Catarina, Brazil, March, 1983

\begin{tabular}{|c|c|c|c|c|c|c|c|c|}
\hline \multirow{3}{*}{$\begin{array}{l}\text { Direction } \\
\text { of } \\
\text { dispersion }\end{array}$} & \multicolumn{4}{|c|}{ Initial captures } & \multicolumn{4}{|c|}{ Follow - up captures } \\
\hline & \multirow{2}{*}{ Date } & \multirow{2}{*}{$\begin{array}{l}\text { Hour of } \\
\text { capture }\end{array}$} & \multirow{2}{*}{$\begin{array}{l}\text { Mosquitoes } \\
\text { captured, } \\
\text { stained \& } \\
\text { released } \\
\end{array}$} & \multirow{2}{*}{$\begin{array}{l}\text { Hour of } \\
\text { relcase }\end{array}$} & \multirow{2}{*}{ Date } & \multirow{2}{*}{ Hour } & \multicolumn{2}{|c|}{ Mosquitoes } \\
\hline & & & & & & & Captured & With stain \\
\hline $\begin{array}{l}\text { Canopy } \\
\text { to ground }\end{array}$ & March, 3 & $16: 00-19: 55$ & 1000 & $20: 40$ & $\begin{array}{l}\text { March, } 3 \\
\text { March, } 4 \\
\text { March, } 4\end{array}$ & $\begin{array}{r}20: 40-21: 20 \\
5: 30-7: 00 \\
17: 30-19: 30\end{array}$ & $\begin{array}{l}220 \\
266 \\
550\end{array}$ & $\begin{array}{r}0 \\
77 \\
17\end{array}$ \\
\hline & March, 5 & $17: 30-20: 30$ & 650 & $21: 00$ & March, 6 & $6: 00-13: 30$ & 70 & 29 \\
\hline $\begin{array}{l}\text { Ground to } \\
\text { canopy }\end{array}$ & March, 4 & $17: 30-19: 30$ & 533 & $21: 00$ & $\begin{array}{l}\text { March, } 5 \\
\text { March, } 5\end{array}$ & $\begin{array}{r}7: 30-9: 00 \\
17: 30-20: 30\end{array}$ & $\begin{array}{r}11 \\
654\end{array}$ & $\begin{array}{l}6^{*} \\
4\end{array}$ \\
\hline
\end{tabular}

*plus 1 yellow-stained.

In addition to these experiments, among the many mosquitoes that were biting us inside a car stationed on the road about 100 meters from the experimental tree, we found two yellow-stained $A$. cruzi, i.e., that had been previously captured and released at the canopy.

\section{COMMENTS}

Although not ruling out the possibility of $A$. cruzi being two species, both capable of vertical movement in the forest, the present experiments favour the assumption that the canopy and ground populations belong to a single species. The experiments proved that a considerable proportion of females feeding at the canopy can come down, and those biting on the ground can go up to feed on blood. We have previously shown that $A$. cruzi can attack, in large numbers, species of Brazilian monkeys that are hosts of plasmodia infective for humans (Deane, 1976), and a "semi-natural" infection due to Plasmodium simium was acquired by one of our field assistants who performed, on himself, the canopy mosquito catches at the Cantareira forest reserve in São Paulo, where, as mentioned above, $A$. cruzi rarely comes down to feed and human malaria is absent (Deane, Deane \& Ferreira Neto, 1966). Therefore, the possibility of occurrence of human cases of naturally acquired malaria of simian origin in particular areas should be kept in mind. Such cases would hardly interfere with the anti-malaria campaign in Brazil, because even in areas 
where $A$. cruzi was shown to be eclectic as to the forest level where its females feed, human malaria has apparently been successfully eradicated (Deane, 1969). But they could explain the origin of sporadic human cases which might eventually appear during the vigilance stage of the campaign and apparently unconnected with other human patients.

\section{RESUMO}

Pintando fêmeas de Anopheles cruzi com pós fluorescentes coloridos, numa floresta de Santa Catarina, mostramos que elas movimentam-se da copa ao solo e vice-versa para se alimentar de sangue. Isso sugere que em áreas onde esse mosquito for transmissor das malárias humana e simiana pode-se esperar que ocorram infeç̧ões humanas esporádicas por plasmódios de macacos.

\section{ACKNOWLEDGEMENTS}

Our thanks are due to the administrative personnel and the devoted field staff of SUCAM in São Francisco do Sul, Srs. Acácio Pereira, Orlando Paulo and Moacir Wollinger, for their indispensable help during these experiments.

\section{REFERENCES}

CONTACOS. P.: LUNN, J.S.: COATNEY, G.R.; KILPATRICK, J.M. \& JONES, F.E., 1963. Quartan rjpe malaria parasites of New World monkeys transmissible to man. Science 142:676.

DLANF, L.M., 1969. Plasmod'a of monkeys and malaria cradication in Brazil. Rev. inter-Amer. Microbiol. Parasitol. 11 69-73.

DEANF. L.M., 1976. Epidemiology of simian malaria in the American Continent. In First Inter-American Conference on Conservation and Litilization of American Non-Human Primates in Biomedical Research. Panamer. Hlth. Org., Scient. publ. no. $317: 147-163$.

DEANE. L.M.: DEANE, M.P. \& FERREIRA NETO, J.A., 1966. Studies on transmission of Simian Malaria and on a natural infection of Man with Plasmodium simium in Brazil. Bull. Wld. Hlth. Org. $35: 805-808$.

DEANE, L.M.; DEANE, M.P.; FERREIRA NETO, J.A. \& ALMEIDA, F.B., 1971. On the transmission of Simian Malaria in Brazil. Rev. Inst. Med. trop. Säo Paulo I3:311-319.

DEANE, L.M.; FERREIRA NETO, J.A.; DEANE, M.P. \& SILVEIRA, I.P.S., 1970. Anopheles (Kerteszia) cruzi, a natural vector of the monkey malaria parasites, Plasmodium simium and Plasmodium brasilianum. Trans. roy. Soc. trop. Med. Hyg. $64: 647$. 